\title{
Tax system reforms and the impact on economic development in Kosovo
}

\author{
Shkendije (Demalijaj) Ukaj \\ Tax Administration of Kosovo \\ sh_demalijaj@yahoo.com
}

DOI:10.5901/mjss.2014.v5n19p114

\begin{abstract}
Public administration reforms which aim to increase the performance and efficiency of the public sector in Kosovo and in particular the reforms in order to increase the efficiency of the tax system are the object of study in this paper. Public administration of a state that will approach the European Union should reach the quality level of administration that exists within the European Administrative space while, in Kosovo have done much to build efficient public sector and responsible to increase transparency and to encourage private sector development that is just as important for country's development perspective and to improve social cohesion in the longer term. The impact of the public sector to economic growth is of special interest in the Southeastern European countries as well as in Kosovo. Tax policy has always been at the center of reforms regarding tax rates and structure to adapt to the growing private sector. Problems revenue collection, the main administrative reforms, comparative analysis with countries in the region in relation to the performance of tax revenues to determine the benefits of citizens from public spending are the focus of this paper. For the design of this paper is the use of literature and material consists of works by different authors, the use of sources of information from the official websites of the most important national and international character, OECD, IMF, WB to provide information for a comparative analysis Kosovo to other countries as well as 14 years of professional experience in the field of copyright.
\end{abstract}

Keywords: tax system, tax principles, tax reforms, tax rates, tax policy .

\section{Introduction}

Government to perform certain functions of its administration, the required inter alia: (i) collection of resources from the economy, to allow sufficient and adequate, (ii) the distribution and use of these resources responsibly, efficiently and effectively (OECD 2004).

Political, economic and social development of any country depends on the amount of revenue generated for the provision of infrastructure in that country. While to generate the necessary income is a tax system is structured. The tax system is an opportunity for the government to raise additional revenue for the performance of its duties and the creation of a favorable environment for economic stimulation. In this aspect, "Tax is a major player in every society of the world" (Ogbonna G N, Ebimobowei A, 2012).

Even economists and politicians have long understood the importance of tax and demanded a set of principles to guide tax policy, centuries ago, the French state husband, Jean Baptiste Colbert suggested: " The art of taxation is the art of removing the feathers of a goose, for as many feathers as possible and with as little crying by her side". Modern economics takes into account a less cynical theory, with emphasis on how to settle taxes to ensure efficiency in the economy and a fair distribution of income ( Rosen $\mathrm{H}, 2003$ ).

Tax experts should in clear terms state that the tax system needs to be reformed to achieve long-term economic growth of a country. Tax reform is a continuous process of tax policy makers and tax administrators to reflect constantly adapting tax systems and economic change. However, economic growth can not be achieved only with tax reform processes and their compliance with macroeconomic objectives without effective measures relating to personnel management fees, accountability and transparency of government officials in the management of income tax (Ogbonna G. N, Ebimobowei A, 2012). Therefore, in this work are reviewed policies and reforms in tax systems, which are related to tax structures and rates of extraction in order of importance out of reforms in the economic growth of a country. 


\section{Tax system and tax system reforms in Kosovo}

Kosovo's tax system is very new, created from the beginning, based largely on the experience of developed western countries. After finishing the 1999 war in Kosovo begins a new era in terms of political, social and economic as well as in the construction of the tax system in general. Tax Administration of Kosovo (TAK) was founded January 17, 2000 under the direction and administration of UNMIK ${ }^{1}$, and since February 2003, transferred the powers of leadership to the Ministry of Economy and Finance and since that time TAK functions as executive agency managed entirely by locals (Tax Administration of Kosovo,2011).

From 1999 to 2003, UNMIK was the creator of the system and tax policy, tax interventions were based mainly on the experiences of other countries and not in compliance with state and real needs that postwar Kosovo. As in all modern countries in Kosovo constitute tax system of different types of taxes, contributions and other fiscal instruments governed by tax laws. Respect tax laws is essential responsibility of every citizen. In a country that Kosovo intends to modern life, from citizens required payment of taxes and other obligations that fund civic programs, public service delivery and the high standard of education, welfare, health, social support, protection, law enforcement and the general infrastructure. All these become possible only with proper collection of taxes (Tax Administration of Kosovo,2010).

Initially TAK its establishment in 2000 has managed to Hotels and Restaurants Tax and presumptive tax are taxed by which all other types of business income. In July of 2001 began applying value added tax (VAT) which replaced the revenues in hotels and restaurants and the presumptive tax quota 50.000.00 $€$ annual turnover while the presumptive continued to operate and also replaced tax on hotels and restaurants under the quota of the above. In April of 2002, has begun to apply the wage tax and income tax for legal entities, who up to that time are taxed with the presumptive tax. By January 2005 became a tax reform, replacing the presumptive tax, wage tax and income tax with two new types of taxes, such as personal income tax, which for tax individuals and tax revenues which for tax corporate legal entities(Tax Administration of Kosovo,2011). So, as noted reforms in transition countries, unlike the tax reforms of developed countries, gave priority to change the structure of the old tax, replacing them with taxes that are applied in developed countries.

The tax system in Kosovo, has evolved from UNMIK regulations system of tax laws issued by the Assembly of the Republic of Kosovo, with what was made possible by the start of the application of the reforms, which meet international standards and principles EU (Tax Administration of Kosovo,2011).

\section{Structure and tax rates}

European tax systems perspective per rely on three pillars: differentiate by type of tax: Tax directly which includes personal income tax, corporate income tax and capital taxes; indirect taxes, which includes VAT and excise taxes on products and production; social contributions. Than, taxes can be classified according to the tax base: and then distinguish between consumption, labor and capital. In the end, taxes are divided by level of government in: central and local (M. Hutsebaut,2013).

Instead, the tax base in Kosovo consists of four types of taxes:

- Value added tax

- Tax Corporate Income

- Personal Income Tax

- Pension Contributions

These types of taxes are changed in order to simplify tax and delivery facilities by reducing the tax rates.

\section{Revenues by type of tax}

${ }^{1}$ Mision Nations States in Kosovo 
Table 1.

Tax structure, Selected European countries, 2006-2011 ( In percent of GDP, general government )

\begin{tabular}{|c|c|c|c|c|c|}
\hline & Tax Revenue & Direct Taxes & Indirect Tax & Trade Taxes & Vat c- efficiency 1 \\
\hline Kosovo & 21.7 & 3.8 & 15.4 & 2.5 & 0.56 \\
\hline Albania & 19.4 & 4.2 & 12.2 & 0.9 & 0.49 \\
\hline Bosnia \& Herzegovina & 23.3 & 3.4 & 17.9 & 2.1 & 0.79 \\
\hline Bulgaria & 22.1 & 6.8 & 15.0 & 0.3 & 0.60 \\
\hline Croatia & 22.3 & 5.8 & 15.3 & 0.5 & 0.66 \\
\hline Czech Republic & 20.1 & 8.5 & 10.7 & 0.0 & 0.46 \\
\hline Hungary & 26.1 & 10.4 & 11.9 & 0.0 & 0.40 \\
\hline Latvia & 20.0 & 8.7 & 10.6 & 0.2 & 0.40 \\
\hline Lithuania & 19.2 & 8.1 & 10.7 & 0.0 & 0.43 \\
\hline Macedonia & 20.3 & 4.5 & 12.8 & 1.6 & 0.52 \\
\hline Montenegro & 24.9 & 5.6 & 16.3 & 1.6 & 0.66 \\
\hline Poland & 21.3 & 8.5 & 12.0 & 0.0 & 0.43 \\
\hline Romania & 18.4 & 6.7 & 10.9 & 0.3 & 0.41 \\
\hline Serbia & 25.0 & 6.9 & 16.0 & 1.9 & 0.67 \\
\hline Slovak Republic & 17.0 & 6.0 & 9.8 & 0.0 & 0.47 \\
\hline Slovenia & 22.9 & 8.7 & 12.3 & 0.3 & 0.58 \\
\hline Turkey & 19.1 & 6.7 & 0.0 & 0.3 & 0.34 \\
\hline Unweighted average2/ & 21.3 & 6.8 & 12.8 & 0.6 & 0.52 \\
\hline
\end{tabular}

Sources: Government Financial Statistics (IMF), and country documents.

$1 /$ Vat collection in percent of total consumption, divided by the standard VAT rate

2/ Excluding Kosovo.

As seen from the table tax - GDP ratio is about $22 \%$, and is comparable to the average in the period 2006-2011 Eastern Europe , more than $80 \%$ of tax revenues constitute indirect taxes, which most of them harvested at the border , the trade tax is the largest in the region, the income to be threatened by the steps taken towards free trade (M.Keen, T.Baunsgaard,2010).

What gives to understand that the need for a gradual reform of the tax system in Kosovo, avoid unnecessary costs or tax exemptions and review of very low rates as the tax on corporate income as well as personal ones (M. Grote et al.,2011).

Table 2.

Total taxes (including social security contributions) and tax structure, \% of GDP, 2000-2010, EU-27

\begin{tabular}{|c|c|c|c|c|c|c|}
\hline & 2000 & 2002 & 2004 & 2006 & 2008 & 2010 \\
\hline \multicolumn{7}{|c|}{ Structure by type of tax } \\
\hline Indirect taxes & 13.7 & 13.3 & 13.3 & 13.5 & 13.1 & 13.2 \\
\hline VAT & 7.0 & 6.8 & 6.8 & 7.0 & 6.9 & 7.0 \\
\hline
\end{tabular}




\begin{tabular}{lrrrrrr} 
Excise duties\&cons.taxe & 3.0 & 3.0 & 2.9 & 2.7 & 2.6 & 2.7 \\
Other taxes on products & 1.7 & 1.6 & 1.7 & 1.8 & 1.6 & 1.5 \\
Other taxes on production & 2.0 & 2.0 & 2.0 & 2.0 & 2.0 & 2.0 \\
Direct taxes & 14.1 & 13.1 & 12.8 & 13.7 & 13.8 & 12.6 \\
Personal income & 9.8 & 9.4 & 8.9 & 9.2 & 9.4 & 9.1 \\
Corporate income & 3.1 & 2.6 & 2.7 & 3.3 & 3.0 & 2.4 \\
Other & 1.1 & 1.1 & 1.2 & 1.2 & 1.3 & 1.2 \\
Social contributions & 12.7 & 12.5 & 12.6 & 2.4 & 12.5 & 12.7 \\
Employers' & 7.2 & 7.2 & 7.2 & 7.1 & 7.2 & 7.3 \\
Employees' & 4.1 & 3.9 & 3.9 & 3.8 & 3.8 & 3.8 \\
Self-and non-employed & 1.4 & 1.4 & 1.5 & 1.5 & 1.5 & 1.5 \\
& & & & & & 38.4 \\
\hline
\end{tabular}

Source: Commission services

Also as seen from the above table tax- GDP ratio in the EU - 27 countries is so much bigger is 38.4 in 2010 , the participation of indirect taxes is much smaller in comparison with Eastern Europe while direct taxes (12.6\%) and pension contributions (12.7\%), are in much larger participation compared with the above countries and in particular compared to Kosovo.

It is worth noting that unlike the EU countries where the GDP, revenues are part of the social contributions, in Kosovo these are excluded, you appreciate that it is a very big bull on the budget, even as poor of this country, because they are administered by TAK but managed by an independent body called pension Savings Trust and held in personal accounts of individuals who pay (the Employed $5 \%$ per month) and for whom paid (employer $5 \%$ per month). That amount represents more than one third of general tax revenues administered by TAK.

\section{Tax rate reforms ( Recent reforms of the tax systems in EU from 2011 to 2012)}

Reforms are sometimes difficult to achieve because they create winners and losers but then overcome prejudices to maintain the Status QUO. Financial and economic crisis that started in 2008 has resulted in a deterioration of public finances in many EU countries. Consequently, fiscal policy in 2011 and 2012 are typically driven to bring public finances on a sustainable path. However, tax reforms in the EU in 2011 and 2012 have responded more necessary that the consolidation of public finances, including revenue side, which is reflected in the increase of the tax burden in general including social insurance (European Commission, 2012).

Table 3.

Statutory tax rates (2000-2012), in \% and the composition of tax wedge in 2011, sigle average income worker.

Personal income tax rate Adjusted top corporate income tax rate Income tax plus employees' and employers' social security contributions(as \% of labour costs,2011)

\begin{tabular}{|c|c|c|c|c|c|c|c|c|c|c|c|c|c|c|}
\hline \multicolumn{2}{|c|}{$\begin{array}{l}2000 \\
\text { Country } \\
\end{array}$} & \multirow{2}{*}{\multicolumn{2}{|c|}{$\begin{array}{ll}2005 \quad 2010 \\
6 & 53.7 \quad 53.7\end{array}$}} & \multirow{2}{*}{2011} & \multirow{2}{*}{$\begin{array}{r}2012 \\
53.7\end{array}$} & \multirow{2}{*}{$\frac{2000}{40.2}$} & \multirow{2}{*}{$\begin{array}{r}2005 \\
34.0\end{array}$} & \multirow{2}{*}{$\begin{array}{r}2010 \\
34.0\end{array}$} & & \multirow{2}{*}{$\frac{112012}{34.0}$} & \multirow{2}{*}{$\begin{array}{c}\text { Tax wedge } \\
55.5\end{array}$} & \multirow{2}{*}{$\begin{array}{c}\text { Income tax } \\
21.7\end{array}$} & \multicolumn{2}{|c|}{$\begin{array}{l}\text { Employee SSC } \\
\text { Employer SSC }\end{array}$} \\
\hline $\mathrm{BE}$ & 60.6 & & & & & & & & & & & & 10.8 & 23 \\
\hline$B G$ & 40.0 & 24.0 & 10.0 & 10.0 & 10.0 & 32.5 & 15.0 & 10.0 & 10.0 & 10.0 & 32.5 & 7.4 & 11.0 & 15.5 \\
\hline$C Z$ & 32.0 & 32.0 & 15.0 & 15.0 & 15.0 & 31.0 & 26.0 & 19.0 & 19.0 & 19.0 & 42.5 & 8.9 & 8.2 & 25.4 \\
\hline
\end{tabular}


$\begin{array}{lllllllllll}\text { DK } & 62.9 & 62.3 & 55.4 & 55.4 & 55.4 & 32.0 & 28.0 & 25.0 & 25.0 & 25.0\end{array}$

DE $\quad \begin{array}{llllllllll}53.8 & 44.3 & 47.5 & 47.5 & 47.5 & 51.6 & 38.7 & 29.8 & 29.8 & 29.8\end{array}$

EE $\quad \begin{array}{llllllllll}26.0 & 24.0 & 21.0 & 210 & 21.0 & 26.0 & 24.0 & 21.0 & 21.0 & 21.0\end{array}$

IE $\quad \begin{array}{llllllllll}44.0 & 42.0 & 41.0 & 41.0 & 41.0 & 24.0 & 12.5 & 12.5 & 12.5 & 12.5\end{array}$

$\begin{array}{lllllllllll}\text { EL } & 45.0 & 40.0 & 49.0 & 49.0 & 49.0 & 40.0 & 32.0 & 34.0 & 30.0 & 30.0\end{array}$

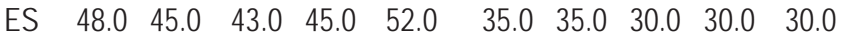

$\begin{array}{lllllllllll}\text { FR } & 59.0 & 53.5 & 45.8 & 46.7 & 46.8 & 37.8 & 35.0 & 34.4 & 34.4 & 36.1\end{array}$

$\begin{array}{lllllllllll}\text { IT } & 45.9 & 44.1 & 45.2 & 47.3 & 47.3 & 41.3 & 37.3 & 31.4 & 31.4 & 31.4\end{array}$

$\begin{array}{lllllllllll}\text { CY } & 40.0 & 30.0 & 30.0 & 30.0 & 38.5 & 29.0 & 10.0 & 10.0 & 10.0 & 10.0\end{array}$

LV $\quad \begin{array}{llllllllll}25.0 & 25.0 & 26.0 & 25.0 & 25.0 & 25.0 & 15.0 & 15.0 & 15.0 & 15.0\end{array}$

$\begin{array}{lllllllllll}\text { LT } & 33.0 & 33.0 & 15.0 & 15.0 & 15.0 & 24.0 & 15.0 & 15.0 & 15.0 & 15.0\end{array}$

LU $\quad \begin{array}{llllllllll}47.2 & 39.0 & 39.0 & 42.1 & 41.3 & 37.5 & 30.4 & 28.6 & 28.8 & 28.8\end{array}$

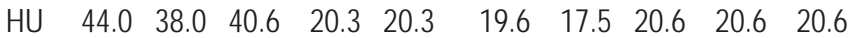

MT $\quad \begin{array}{llllllllll}35.0 & 35.0 & 35.0 & 35.0 & 35.0 & 35.0 & 35.0 & 35.0 & 35.0 & 35.0\end{array}$

$\begin{array}{lllllllllll}\mathrm{NL} & 60.0 & 52.0 & 52.0 & 52.0 & 52.0 & 35.0 & 31.5 & 25.5 & 25.0 & 25.0\end{array}$

AT $\quad \begin{array}{llllllllll}50.0 & 50.0 & 50.0 & 50.0 & 50.0 & 34.0 & 25.0 & 25.0 & 25.0 & 25.0\end{array}$

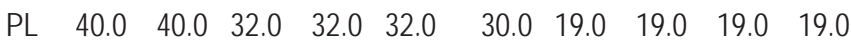

$\begin{array}{lllllllllll}\text { PT } \quad 40.0 & 40.0 & 45.9 & 50.0 & 49.0 & 35.2 & 27.5 & 29.0 & 29.0 & 31.5\end{array}$

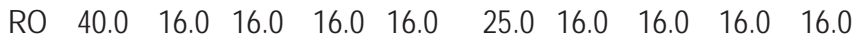

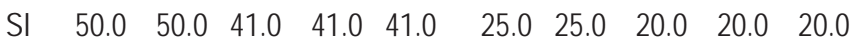

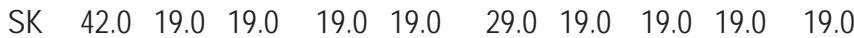

$\begin{array}{lllllllllll}\text { FI } & 54.0 & 51.0 & 49.0 & 49.2 & 49.0 & 29.0 & 26.0 & 26.0 & 26.0 & 24.5\end{array}$

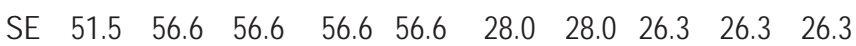

$\begin{array}{lllllllllll}\text { UK } & 40.0 & 40.0 & 50.0 & 50.0 & 50.0 & 30.0 & 30.0 & 28.0 & 26.0 & 24.0\end{array}$
38.4

28.0

$10.7 \quad 0.0$

49.8

15.9

$17.4 \quad 16.5$

40.1

12.5

$2.1 \quad 25.6$

26.8

13.5

3.6

9.7

$\begin{array}{llll}38.0 & 3.0 & 12.8 & 22.2\end{array}$

39.9

12.0

4.9

23.0

49.4

10.0

9.6

47.6

16.1

7.2

29.7

13.9

2.1

5.9

24.3

44.2

14.9

$7.3 \quad 19.4$

40.7

10.1

$6.9 \quad 23.8$

36.0

13.3

$11.7 \quad 11.0$

49.4

13.6

$13.6 \quad 22.2$

22.4

8.5

6.9

6.9

37.8

14.5

14.0

9.2

$\begin{array}{llll}48.4 & 11.9 & 14.0 \quad 22.6\end{array}$

$\begin{array}{llll}34.3 & 5.9 & 15.5 & 12.9\end{array}$

$\begin{array}{llll}39.0 & 10.9 & 8.9 & 19.2\end{array}$

$\begin{array}{llll}44.3 & 9.3 & 12.8 & 22.3\end{array}$

$\begin{array}{llll}42.5 & 9.6 & 19.0 \quad 13.9\end{array}$

$\begin{array}{llll}38.9 & 7.5 & 10.6 \quad 20.8\end{array}$

$\begin{array}{llll}42.7 & 18.5 & 5.8 & 18.4\end{array}$

$\begin{array}{llll}42.8 & 13.6 & 5.3 & 23.9\end{array}$

32.5

14.1

$8.5 \quad 9.9$

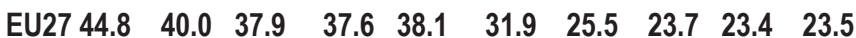

43.7

13.7

$10.7 \quad 19.3$

Source: Commission services (See European Commission, 2012).

So, as seen from the table above, some countries have increased personal income tax while some others have reduced the tax rates on corporate income. The social contributions are increasing in many countries leads by means increase in the standard rate, as well as the applicable rates for special groups .

Table 4.

\begin{tabular}{|c|c|c|c|c|c|c|c|c|c|c|c|c|c|}
\hline \multicolumn{14}{|c|}{ Standard and reduced VAT rates in the EU-27 } \\
\hline Country's & 2000 & 2001 & 2002 & 2003 & 2004 & 2005 & 2006 & 2007 & 2008 & 2009 & 2010 & 2011 & 2012 \\
\hline EU-27 & 19.2 & 19.3 & 19.5 & 19.5 & 19.4 & 19.6 & 19.4 & 19.5 & 19.4 & 19.8 & 20.4 & 20.7 & 21.0 \\
\hline
\end{tabular}

Source: Commission services ( see European Commission, 2012). 
As seen from table, EU-27 states have increased the average rate of VAT, in recent years. Approximately half of the member states have raised VAT rates.EU tax composition, there is a difference not only in the general level of taxation but also in its composition. Nordic Country and United Kingdom have relatively high levels of direct taxes in total tax revenues. In Denmark, a small measure in Sweden and the United Kingdom, the share of social contributions is low due to the fact that most welfare spending financed by general taxation, this requires high levels of taxation to direct taxation, of which Denmark is the highest in the EU. With high \% of the social security and relatively low direct taxes, German and French tax systems are the opposite of Denmark.

\section{Reforms regarding tax rates in Kosovo}

From January 2009 has started to apply the new law to discount the tax rates in Kosovo. Taxes on corporate income decreased from $20 \%$ to $10 \%$, VAT undergoes an increase of $15 \%$ to $16 \%$ while the tax on personal income had fallen as shown in the following table.

Table 5.

\begin{tabular}{|c|c|c|c|}
\hline \multicolumn{4}{|c|}{ Taxes on Personal Income and tax rates in\% } \\
\hline \multicolumn{2}{|c|}{ The average Personal Income in $€$} & Tax rates in \% \\
\hline Monthly & Annual & $0 \%$ & From January 2009 \\
\hline Up to 80 $€$ & Up to 960€ & $5 \%$ & $0 \%$ \\
\hline $80-250 €$ & $960-3000 €$ & $10 \%$ & $4 \%$ \\
\hline $250-450 €$ & $3000-5400 €$ & $20 \%$ & $8 \%$ \\
\hline Over 450€ & Over 5400 & & $10 \%$ \\
\hline
\end{tabular}

While in mid -2012 there was an increase in the tax rate from $5 \%$ to $9 \%$ for businesses involved in service activities, whose annual turnover does not reach the amount above 50.000.00€.

\section{Data on the growth of Kosovo into perspective}

Kosovo's economy grew by an average of $4.3 \%$ in the last decade (2003-2012) to set Kosovo on top of the region, however insufficient to generate satisfactory improvements in the standard of life. Population growth, $1.5 \%$ with the largest in the region, while per capita GDP $2.8 \%$ lower in the region, also index of consumer prices, to $2.3 \%$ the highest in the region ( International Monetary Fund, 2013 ).

This shows that despite that Kosovo had economic growth and the crisis of 2008 has not affected the economy of Kosovo, Kosovo revenues are small per capita and that despite the lower tax rates and reforming the system despite administration largely tax , Kosovo is achieving success in collecting enough revenue, as a result of the presence of the informal economy and corruption that the presence of public officials .

Initiatives to streamline business registration and to protect investors helped Kosovo to climb 30 stairs in the World Bank report where we Chuang ranked 98th (World Bank, 2013).

\section{Conclusions}

The purpose of this paper is to reflect the impact of the tax system reform in economic development. Here's tax reforms have significantly changed the functioning of the tax system resulting in improving the impact of economic growth. Desirable social spending will translate into growth in output and growth in real per capita basis to ensure efficient use of government tax revenue from various reforms. 
However desired income can not be generated from tax -free review of outdated laws and tax rates without promoting fiscal responsibility, efficient administration with a staff without corruptive, well trained and motivated to progress in achieving the objectives macroeconomic and above all accountability and transparency by government officials in the management of income tax for the benefit of the citizens of that country .

\section{Recommendations}

- Policies that would promote growth with its own forces include improvement in governance and business climate.

- Tax structure should be adapted to progress towards EU integration over the economy and more towards domestic production, gradually shifting towards direct taxation.

- Expand the tax base by revising tax rates low directly.

-Tight control transaction in certain sensitive areas and economic: art, gold, jewelery, private medical services.

- Increasing professional tax officials mainly on the concrete provisions specialization works.

- Raise the level of responsibility and Accountability that tax officials.

- Organize steps in combating the informal economy as well as to businesses to the informal - Employed registered obligation to employees prior to starting work.

- Kosovo institutions to take concrete steps to combat corruption among public officials.

\section{References}

OECD, Menaxhimi i shpenzimeve publike / Një libër reference per vendet ne tranzicion, Tiranë, (2004), fq.17. / OECD, Managing Public Expenditure/ A Reference Book of Transition Countries, Edited by Richard Allen \& Daniell Tommasi, Copyright@2004 OECD, p.17.

Rosen H, "Public Finance", Department of Economics, Princeton University, Sixth Edition, 2003, pp.305-338. ISBN 0-07237405-5.

M.Keen, T.Baunsgaard (2010): Tax revevue and Trade Liberalization, Journal of Public Economics,

94, pp. 563-77.

Ogbonna G N, Ebimobowei A, (2012), Impact of Tax Reforms and Economic Growth of Nigeria: A Time series Analysis, Current Research Journal of Social Sciences, pp. 62-68. ISSN: 2041-3246

European Commission, (2012), Tax reforms in EU Member States, Directorate General for Taxation and Costums Union, No.34, pp.112-117. DOI 10.2778/30527. ISBN 978-92-79-26383-5. http://ec.eurpoa.eu/taxation_costums/taxation lindex_en.htm

International Monetary Fund, (2013), Republic of Kosovo: Staff Report for the Consultation, Paper IV, June 28, 2013, pp. 16-22.

\section{http://www.imf.org/external/np/sec/misc/qualifiers.htm}

M. Grote et al., "Kosovo: Reform Proposals Towards a More Balanced and Revenue-Productive Tax System", FAD

Technical Assistance Report, 2011

M. Hutsebaut, (2013), "Politikat Tatimore sipas kendveshtrimit Europian"' "Tax Policy European point of view", April, 2013, p.7. www.bspk.org/PDF/4_4_13

Tax Administration of Kosovo, “Kosovo's Tax Legislation”, Vol. I, March, 2010, Prishtina, pp.7-8.

www. atk-ks.org

Tax Administration of Kosovo, "Strategy of Fulfillment 2012-2015", September, 2011, Pristina, pp.8-10.

www.atk-ks.org

World Bank, (2013), Report: “Doing Business 2013 ”, fq 4. 